\title{
STUDY ON CLINICAL PROFILE AND CAUSES OF HYPOKALAEMIC PERIODIC PARALYSIS
}

\author{
Natarajan Ramesh ${ }^{1}$, Sappani Kasipandian'2, Meenakshi Sundaram Rajasekaran ${ }^{3}$
}

${ }^{1}$ Assistant Professor, Department of Medicine, K.A.P. Viswanatham Government Medical College, Tiruchirappalli, Tamilnadu. ${ }^{2}$ Associate Professor, Department of Medicine, K.A.P. Viswanatham Government Medical College, Tiruchirappalli, Tamilnadu. ${ }^{3}$ Associate Professor, Department of Medicine, K.A.P. Viswanatham Government Medical College, Tiruchirappalli, Tamilnadu.

\section{ABSTRACT}

\section{BACKGROUND}

Hypokalaemic Periodic Paralysis (HPP) is a Channelopathy which affects the musculoskeletal, nervous, endocrine or metabolic systems and is characterised by episodic skeletal muscular weakness and paralysis in the setting of hypokalaemia. It is classified into primary and secondary types. Based on the clinical studies, the most common cause of HPP in India is Primary Familial Hypokalaemic Periodic Paralysis (FHPP). Identifying the reversible causes of HPP will help in optimising management protocols with specific therapy.

\section{MATERIALS AND METHODS}

In this study, we analysed the clinical profile and causes of HPP in 50 patients with the clinical background of episodic muscular weakness due to Hypokalaemia alone admitted in the General Medicine and Neurology wards at M.G.M. Govt. Hospital, Tiruchirappalli, with age from 17 to 68 years of both males and females over one-year period. The mean duration of illness before presentation was 28 months (range 5 to 70 months) and they had a mean of 4 episodes of HPP (median 3, range 1 to 6 episodes). The data of all patients who presented with HPP were analysed.

\section{RESULTS}

In our study of the total 50 patients, 43 (86\%) were males and 7 (14\%) were females. We found 96\% (48) patients with primary FHPP and 4\% (2) patients with secondary HPP, of which 2\% (1) patients with Gitelman Syndrome (G.S.) and another 2\% (1) patients with Distal Renal Tubular Acidosis (RTA).

\section{CONCLUSION}

From this study, the patients presented with sudden onset of paralysis and markedly low serum (Sr.) potassium ( $\mathrm{K}^{+}$) levels, typical of HPP. Its symptoms resolved completely and quickly following correct treatment depending upon the clinical status and causes. HPP can be fatal if the diagnosis and treatment was not done at appropriate time.

\section{KEYWORDS}

Hypokalaemic Periodic Paralysis, Protein Gradient, Albumin Gradient, Renal Tubular Acidosis, Gitelman Syndrome.

HOW TO CITE THIS ARTICLE: Ramesh N, Kasipandian S, Rajasekaran MS. Study on clinical profile and causes of hypokalaemic periodic paralysis. J. Evolution Med. Dent. Sci. 2017;6(50):3862-3866, DOI: 10.14260/Jemds/2017/834

\section{BACKGROUND \\ HPP is a rare inherited disorder, which is defined as acute} loss of muscle power with inability to walk and documented Sr. $\mathrm{K}^{+}$level < 3.5 milliequivalents per litre $(\mathrm{mEq} / \mathrm{L})$ during the episodes. HPP is characterised by periods of muscular weakness, severe acute paralysis which lasts for hours or even to days, and 3 to 4 times more common in males. ${ }^{1}$ Females usually will have early age of onset than males. Typical episodes occur early in the morning. ${ }^{2}$ Frequency of episodes usually decreases with increasing age, up to $2 / 3^{\text {rd }}$ of patients develop persistent weakness.

HPP may present with acute paralysis which may be fatal, and if diagnosed early and corrected complications can be avoided.

Financial or Other, Competing Interest: None.

Submission 22-02-2017, Peer Review 09-06-2017,

Acceptance 16-06-2017, Published 22-06-2017.

Corresponding Author:

Dr. Sappani Kasipandian,

"Devi Illam," No. 3/423/5,

Meenakshi Amman Street,

Opp. to Pandi Kovil,

Pandian Nagar, Madurai - 625020

E-mail: sankarkasipandian@yahoo.com

DOI: $10.14260 /$ jemds $/ 2017 / 834$
In spite of the fact that most of these cases are due to $\mathrm{Ca}^{+}$ $>\mathrm{Na}^{+}$ion channel mutations and some may be due to potentially reversible causes.

HPP episodes can present daily or weekly or monthly. The normal of $\mathrm{Sr}$. $\mathrm{K}^{+}$level is 3.5 to $5.2 \mathrm{mEq} / \mathrm{L}$, and the total body $\mathrm{K}^{+}$store is $50 \mathrm{mEq} / \mathrm{L} / \mathrm{kg}$ body weight. In moderate hypokalaemia, the $\mathrm{Sr} . \mathrm{K}^{+}$is 2.5 to $3 \mathrm{mEq} / \mathrm{L}$ and in severe hypokalaemia $\mathrm{Sr} . \mathrm{K}^{+}$concentration is $<2.5 \mathrm{mEq} / \mathrm{L}$. $\mathrm{K}^{+}$is a major intracellular ion constituting $200-400 \mathrm{mEq} / \mathrm{L} \mathrm{(97 \% )}$ of total body store and a minor extracellular $\mathrm{K}^{+}$is 3.5 to 5.0 $\mathrm{mEq} / \mathrm{L}(3 \%)$ of the total body $\mathrm{K}^{+}$store. $\mathrm{K}^{+}$plays an important role in determining the cell membrane potential; even a minimum change of $\mathrm{K}^{+}$concentration may cause serious alterations in the functioning of cardiovascular and neuromuscular systems. In order to differentiate hypokalaemia due to renal loss of $\mathrm{K}^{+}$from non-renal loss, estimation of Transtubular $\mathrm{K}^{+}$concentration Gradient (TTKG) during paralytic attack is helpful.

$\mathrm{TTKG}^{4}=\left[\right.$ Urine $\mathrm{K}^{+} /$Plasma $\left.\mathrm{K}^{+}\right] /[$Urine osmolality/blood osmolality]

TTKG $>3.0$ and Urine $\mathrm{K}^{+}$level $>20(\mathrm{mmol} / \mathrm{L})$ shows renal $\mathrm{K}^{+}$loss.

Urine $\mathrm{K}^{+}$/ Cr. level > 2.5 - favours Renal loss of more $\mathrm{K}^{+}$

Electrocardiograph (ECG) ${ }^{3}$ in mild hypokalaemia shows S$\mathrm{T}$ depression, flattened $\mathrm{T}$ waves and prominent $\mathrm{U}$ waves and 
in severe hypokalaemia it shows peaked $\mathrm{P}$ waves, prolonged PR interval and widened QRS complex. In Primary HPP weakness can be precipitated by factors like food rich in carbohydrates, high $\mathrm{Na}^{+}$, diuretic and insulin therapy, exposure to cold, stress, upper respiratory tract infections, surgery, pregnancy, severe strenuous exercise the previous day, high alcohol and corticosteroid usage. Prodrome of fatigue, myalgia, stiffening of muscles and diffuse pain are common.

Distal Renal Tubular Acidosis (RTA) (2\%) is an important, medically treatable cause and should be looked for in a proactive manner. ${ }^{1}$ Distal RTA most frequently accompanied by hypokalaemia and associated with acquired systemic illnesses. Distal RTA is characterised by inability to acidify the urine $\mathrm{pH}$ below 5.5, variable hyperchloraemic hypokalaemic metabolic acidosis, hypercalciuria, nephrocalcinosis and nephroloithiasis. ${ }^{4} \mathrm{~K}^{+}$wasting may be particularly severe during acidosis. Sufficient alkali therapy usually corrects the $\mathrm{K}^{+}$wasting, hypokalaemia and metabolic acidosis. ${ }^{5}$

Two types of distal RTA are Autosomal Recessive (AR) and Autosomal Dominant (AD). AR distal RTA is usually diagnosed often before 1 year of age present with vomiting, dehydration, failure to thrive or delayed growth. ${ }^{6} \mathrm{Sr}$. $\mathrm{K}^{+}$levels are also lower in AR type than $\mathrm{AD}(\mathrm{K}<3.5 \mathrm{mEq} / \mathrm{L})$ distal RTA $\left(\mathrm{K}^{+}>3.5 \mathrm{mEq} / \mathrm{L}\right)$. Bilateral sensorineural deafness can be present. ${ }^{7}$ AD distal RTA are usually a milder and often discovered incidentally in patients with nephrolithiasis. Nephrocalcinosis and kidney stones were present in $\approx 50 \%$ of patients. Nephrocalcinosis is a unique marker for classical distal RTA with complication of pyelonephritis. ${ }^{8}$ Salt wasting occurs along with tubulointerstitial disease or advanced nephrocalcinosis.

Gitelman Syndrome (GS) $2 \%$ is caused by mutations in the SLC12A3 gene encoding the thiazide - sensitive $\mathrm{NaCl}$ cotransporter, also known as NCCT. ${ }^{9}$ GS usually have preserved urinary concentrating ability. Inherited as Autosomal Recessive trait and usually diagnosed in adults with hypokalaemia, hypocalciuria, hypomagnesaemia and hypophosphataemia with predominant muscular weakness. ${ }^{10}$

In patient with GS, there is renal loss of Phosphorus $\left(\mathrm{P}^{+}\right)$ sufficient to cause severe hypophosphataemia due to intrinsic tubular defect, Hypokalaemic metabolic alkalosis or renal vasodilation. ${ }^{11}$ There are two types of point mutations genes. Type 1 CACNA1S - $\mathrm{Ca}^{+}$channel with 44 exons $^{12} 60-75 \%$ cases. Type 2 SCN4A - $\mathrm{Na}^{+}$channel with 24 exons in $10-15 \%$ cases. The causes of in both types are due to paradoxical sustained membrane and muscle depolarisation in response to hypokalaemia due to reduction in inward $\mathrm{K}^{+}$currents, especially in ATP-sensitive $\mathrm{K}^{+}$channels.

The primary flaccid weakness is mainly due to inexcitability of Sarcolemma. It results even with minimal change in $\mathrm{Sr}$. $\mathrm{K}^{+}$compared to markedly abnormal level of Sr. $\mathrm{K}^{+}$, in secondary aetiologies. ${ }^{13}$ HPP attack usually lasts for few hours to several days and occur sporadically, sometimes repeated attacks can lead to permanent handicapped including inability to perform routine daily activities. In between attacks, patients may be normal or with minimal weakness. The voltage-gated channel mutations are most common aetiology in HPP.
The paralytic type is more common than myopathic type, $75 \%$ vs. $25 \%$ of HPP patients. ${ }^{14}$ Myopathic type of HPP is a fixed, progressive muscle weakness which occurs at variable age groups, predominantly affecting the lower limbs. Typical attack occurs at early morning. ${ }^{2}$ Paralysis predominantly occurs in lower limbs than in upper limbs. Proximal muscles are significantly affected more than distal. Muscles of eyes, face, tongue, pharynx, larynx, diaphragm and sphincters are very rarely involved. Deep Tendon Reflexes are diminished. Cardiac muscles, respiratory muscles and sensory system are unaffected. Muscle strength between attacks are near normal. After repeated attacks, patient will go on to have permanent proximal weakness. Differential diagnosis for GS are diuretic abuse, laxative abuse and chronic vomiting.

\section{Treatment for HPP}

Normalisation of $\mathrm{Sr}$. $\mathrm{K}^{+}$with oral $\mathrm{KCl}$ syrup $0.2-0.4 \mathrm{mEq} / \mathrm{kg}$ (10 - $20 \mathrm{mEq} /$ day), repeated every $15-30$ mins depending on ECG changes, Sr. $\mathrm{K}^{+}$level and muscle strength (maximum dosage - $40 \mathrm{mEq} /$ day). In emergency situations/vomiting, slow infusion of $\mathrm{IV} \mathrm{KCl}^{15}$ in normal saline should be given with frequent monitoring of serum $\mathrm{K}^{+}$and ECG changes to a maximum of $10-20 \mathrm{mEq} / \mathrm{Hr}$. (maximum of $90 \mathrm{mEq} /$ day) Tab. Acetazolamide 250 to $500 \mathrm{mg} /$ day bd or tds. Treatment for distal RTA are correction of dehydration with normal saline and acidosis with alkali therapy $1-3 \mathrm{mEq} / 1 \mathrm{~kg} /$ day reduces urinary $\mathrm{K}^{+}$excretion, corrects the hypokalaemia, $\mathrm{Na}^{+}$ depletion with sustained correction of metabolic acidosis. So in most of the distal RTA patients, $\mathrm{K}^{+}$supplementation is not necessary. ${ }^{16}$ Treatment for GS is usually with normal saline Magnesium $\left(\mathrm{Mg}^{2+}\right)$ and $\mathrm{K}^{+}$supplementation.

\section{Prevention of Attacks in HPP}

Oral $\mathrm{KCl}$ syrup - $10-20 \mathrm{mEq} /$ day and titrated according to clinical effect.

Acetazolamide - 25 - $200 \mathrm{mg}$ /day bd life-long for $1 \mathrm{HPP}$ only.

\section{Precautions and Adverse Reactions}

Avoid IV $\mathrm{KCl}$ infusion along with 5\% Dextrose Solution (DS), it may worsen the situation.

IV infusion/oral $\mathrm{K}^{+}$supplementation must be monitored to avoid potentially fatal hyperkalaemias and arrhythmias.

Rebound hyperkalaemia may occur in patients who receive > $90 \mathrm{mEq} /$ day of $\mathrm{K}^{+}$containing drugs. Avoid Acetazolamide therapy in type 2 HPP, hypersensitivity, marked hepatic or renal dysfunction, hyponatraemia, hyperchloraemic acidosis and adrenal failure. ${ }^{17}$ In these situations, Dichlorphenamide can be used. Tab. Spironolactone 25 - $200 \mathrm{mg} /$ day also to be given.

\section{Aims and Objectives}

- To evaluate the clinical profile and causes of HPP patients and it is essential for further management and prevent complication and death.

\section{MATERIALS AND METHODS}

\section{Study Setting}

Inpatients admitted in General Medicine and Neurology wards in M.G.M. Govt. Hospital attached to K.A.P.V. Govt. Medical College, Tiruchirappalli, Tamilnadu, South India. 


\section{Consent}

Prior written consent was obtained from all the patients included in this study in their own mother tongue.

\section{Ethical Committee Approval}

Obtained from the Institutional Ethical Committee.

\section{Design of Study}

Descriptive study.

\section{Period of the Study}

January 2016 to January 2017.

\section{Sample Size}

50 patients with the range of 17 - 68 years of age.

\section{Selection of Patients}

\section{Inclusion Criteria}

Patients with signs and symptoms of quadriparesis/ quadriplegia due to hypokalaemia alone.

\section{Exclusion Criteria}

Other neurological diseases causing quadriparesis/ quadriplegia without hypokalaemia.

\section{Study Methodology}

50 patients with HPP were identified over one-year period. Their mean age was 35.02 years (range 17 - 68 years). The mean duration of illness before presentation was 28 months (range 5 - 70 months) and they had a mean of 4 episodes of HPP (median 3, range 1 - 6 episodes). The data of all patients who presented with HPP were analysed. The clinical data collected included age, sex, duration of illness, number of episodes of acute muscular weakness, history of renal stones, bone pain, dry mouth, dry eyes, fractures and a family history of HPP. Clinical examination with special emphasis on pulse rate, blood pressure and a detailed neurological examination were done.

\section{Investigations done Includes}

CBC and ESR, renal function tests including Urine Osmolality and Fasting urinary $\mathrm{pH}$, Sr. electrolytes and Sr. osmolality, Sr. albumin, globulin, alkaline phosphatase, ABG pH, USGabdomen and electrocardiograph.

\begin{tabular}{|c|c|c|c|c|}
\hline Items & Min. & Max. & Mean & S.D \\
\hline Age in Years & 17 & 68 & 35.02 & 9.027 \\
\hline $\mathrm{K}^{+-}$Day $1(\mathrm{mEq} / \mathrm{L})$ & 1.60 & 3.00 & 2.6620 & 0.30297 \\
\hline $\mathrm{K}^{+}-$Day $2(\mathrm{mEq} / \mathrm{L})$ & 1.80 & 3.50 & 3.0560 & 0.26966 \\
\hline $\mathrm{K}^{+-}$Day $3(\mathrm{mEq} / \mathrm{L})$ & 3.30 & 4.00 & 3.6020 & 0.16224 \\
\hline $\mathrm{Na}^{+}(\mathrm{mEq} / \mathrm{L})$ & 135 & 149 & 140.54 & 3.358 \\
\hline RB Sugar (mg/dL) & 80 & 135 & 106.54 & 15.538 \\
\hline $\mathrm{ABG}-\mathrm{pH}$ & 7.32 & 7.50 & 7.4086 & 0.02450 \\
\hline Urine - $\mathrm{pH}$ & 5.40 & 6.80 & 5.5680 & 0.20146 \\
\hline Urine $-\mathrm{K}^{+}$ & 76 & 144 & 94.32 & 13.770 \\
\hline Urine - $\mathrm{Na}^{+}$ & 110 & 160 & 135.84 & 11.393 \\
\hline Blood Urea $(\mathrm{mg} / \mathrm{dL})$ & 20 & 40 & 31.88 & 4.507 \\
\hline Sr. Creatinine (mg/dL) & .60 & 1.20 & 0.9060 & 0.15174 \\
\hline $\mathrm{Mg}^{+}(\mathrm{mEq} / \mathrm{L})$ & .00 & 1.09 & 0.0218 & 0.15415 \\
\hline No. of Episode & 1.00 & 4.00 & 2.3600 & 0.69282 \\
\hline
\end{tabular}

\section{RESULTS}

50 patients were included in our study. Sr. $\mathrm{K}^{+}$levels and other investigations were measured and results were analysed. Among the 50 patients, HPP was observed more commonly in the age group of 17 to 35 years with the mean age of 35.02 years. Of these 50 patients, $43(86 \%)$ were males and 7 (14\%) were females. Male preponderance was seen.

Using one-sample ' $\mathrm{t}$ ' test, there is high statistically significant difference between the sample mean and the normal value of population (P value $<0.001$ ). In our study, 48 (96\%) patients with primary HPP are the most common aetiology for HPP had mean $\mathrm{Sr} . \mathrm{K}^{+}$value of $2.35 \mathrm{mEq} / \mathrm{L} ; 1$ patient (2\%) with GS had Sr. $\mathrm{K}^{+}$value of $1.8 \mathrm{mEq} / \mathrm{L}$ and another one patient ( $2 \%$ ) of distal RTA had $2.0 \mathrm{mEq} / \mathrm{L}$.

Normal ABG-pH in general population is 7.35 to 7.45. In our study, 48 (96\%) patients with primary HPP had mean ABG-pH value of 7.41. One patient (2\%) with GS had ABG-pH value of 7.5 and another one patient $(2 \%)$ with distal RTA had ABG-pH of 7.32.

Normal urinary $\mathrm{K}^{+}$level in the general population is 35 to $100 \mathrm{mEq}$ /day. In our study, 48 (96\%) primary HPP patients were with mean urinary $\mathrm{K}^{+}$value of $90 \mathrm{mEq} /$ day; 1 patient (2\%) with GS had urinary $\mathrm{K}^{+}$value of $137 \mathrm{mEq} /$ day, another 1 patient $(2 \%)$ with distal RTA had high urinary $\mathrm{K}^{+}$than 144 $\mathrm{mEq} /$ day.

Normal urinary pH level in general population is 4.5 to 5.6. In our study, 48 (96\%) primary HPP patients had mean urinary $\mathrm{pH}$ value of 5.2. One patient (2\%) with GS had urinary $\mathrm{pH}$ value of 6.0 and another 1 patient (2\%) with distal RTA had 6.8 .

In our study, ECG showed prominent $U$ waves and flattening of T waves in $48(96 \%)$ patients of HPP and $1(2 \%)$ patient with distal RTA. ECG of $1(2 \%)$ patient with GS showed varying RR interval and absent $P$ wave suggestive of atrial fibrillation.

Sr. $\mathrm{Na}^{+}$, random blood sugar, blood urea and serum creatinine and USG abdomen were normal in all patients and they improved clinically with proper specific treatment.

\begin{tabular}{|c|c|c|c|}
\hline Sex & Patients/No./\% & Age Group & Patients/No./\% \\
\hline Male & $43(86 \%)$ & Age $\leq 35$ Years & $42(84 \%)$ \\
\hline Female & $7(14 \%)$ & Age $>35$ Years & $8(16 \%)$ \\
\hline \multicolumn{4}{|c|}{ Table 2. Age and Sex in HPP $(\boldsymbol{n}=\mathbf{5 0})$} \\
\hline
\end{tabular}

\begin{tabular}{|c|c|c|c|}
\hline $\begin{array}{c}\text { Types of } \\
\text { HPP }\end{array}$ & $\begin{array}{c}\text { Patients } \\
\text { No./\% }\end{array}$ & $\begin{array}{c}\text { Sr. K+ Level } \\
(\mathbf{m E q} / \mathbf{L})\end{array}$ & $\begin{array}{c}\text { Mean Urinary K+/ } \\
\text { Day) }\end{array}$ \\
\hline Primary HPP & $48(96 \%)$ & $2.35(2.66 \pm .3)$ & $90 \mathrm{mEq} /$ day $(94 \pm 6)$ \\
\hline GS & $1(2 \%)$ & 1.8 & $137 \mathrm{mEq} /$ day \\
\hline Distal RTA & $1(2 \%)$ & 2.0 & $144 \mathrm{mEq} /$ day \\
\hline \multicolumn{3}{|c|}{ Table 3. Sr. $\boldsymbol{K}^{+}$Level and Urinary $\boldsymbol{K}^{+}$Levels in HPP } \\
\hline
\end{tabular}

\begin{tabular}{|c|c|c|c|}
\hline $\begin{array}{c}\text { Types of } \\
\text { HPP }\end{array}$ & $\begin{array}{c}\text { Patients } \\
\text { No./\% }\end{array}$ & $\begin{array}{c}\text { ABG-pH } \\
\text { Level }\end{array}$ & $\begin{array}{c}\text { Urinary pH } \\
\text { (Normal 4.5 to 5.5) }\end{array}$ \\
\hline $\begin{array}{c}\text { Primary } \\
\text { FHPP }\end{array}$ & $48(96 \%)$ & $\begin{array}{c}7.41 \\
{[7.40 \pm .02]}\end{array}$ & $5.2[5.5 \pm .3]$ \\
\hline GS & $1(2 \%)$ & 7.5 & 6 \\
\hline Distal RTA & $1(2 \%)$ & 7.32 & 6.8 \\
\hline \multicolumn{4}{|c|}{ Table 4. $\boldsymbol{A B G}$ pH and Urinary $\boldsymbol{p H}$ in HPP } \\
\hline \multicolumn{4}{|c}{}
\end{tabular}




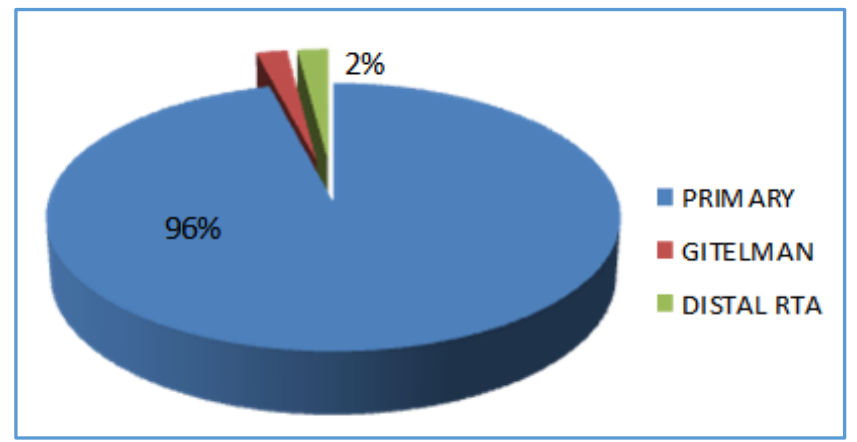

Chart 1. Types of HPP

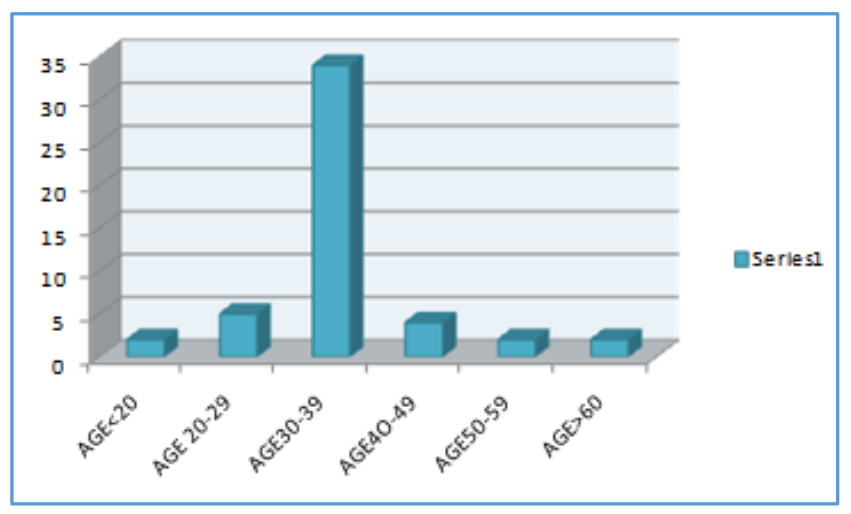

Chart 2. Age Distribution of HPP

[2 pts < 20 yrs.; 5 pts- 20 to 30 yrs.; 34 pts- 30 to 40 yrs.; 4 pts- 40 to 50 yrs.; 2 pts 50 to 60 yrs.; and 2 pts $>60$ ]

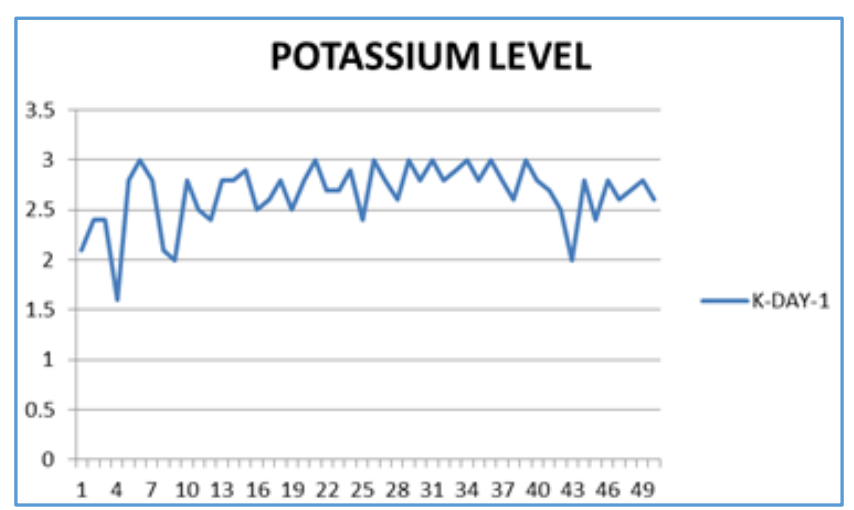

Chart 3. Sr. K+ Level among Patients with HPP

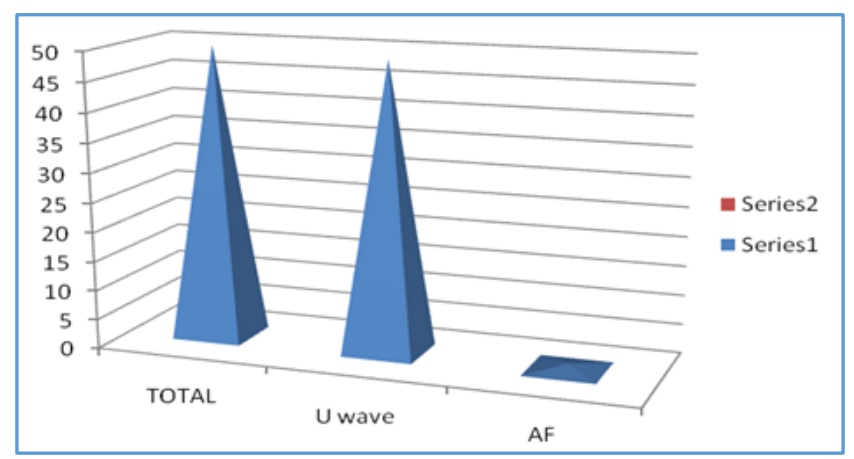

Chart 4 - ECG Finding among Patients with HPP

\section{DISCUSSION}

Among the total 50 patients, $43(86 \%)$ patients were males and 7 (14\%) were females. This was similar to the observation found in other's study on HPP. ${ }^{18}$

The mean age group of our HPP patients was found to be 35.02 years, and more common in the age group of 17 to 35 years which was similar to a large retrospective study involving 226 patients with HPP.

In our study, the mean $\mathrm{Sr} . \mathrm{K}^{+}$value was $2.35 \mathrm{mEq} / \mathrm{L}$ which was similar to Fei-Feng $\mathrm{Li}$ et al 2011 study and they concluded that in HPP episodes of weakness are associated with a decrease in $\mathrm{Sr}$. $\mathrm{K}^{+}$levels, below $2.0 \mathrm{mEq} / \mathrm{L}$ ).

The mean ABG- $\mathrm{pH}$ value, mean urinary $\mathrm{pH}$, mean urinary $\mathrm{K}^{+}$value of patients in our study was $7.41,5.2$ and $90 \mathrm{mEq} / \mathrm{L}$ respectively. It is similar to various clinical studies conducted in patients with HPP (Kung et al 2004).

In our study, we found 49 (98\%) patients (FHPP + Distal RTA). ECG showed flattening of T-wave with prominent Uwave, and remaining one patient $(2 \%)$ showed varying $R R$ interval with absent $\mathrm{P}$-wave suggestive of atrial fibrillation presented in GS. In our study among the 50 patients $48(96 \%)$ patients showed primary FHPP and remaining 2 (4\%) patients showed secondary HPP, of which one $(2 \%)$ was GS and another one $(2 \%)$ was distal RTA. It was found to be statistically significant with $\mathrm{P}$ value $<0.001$ and the most common cause for HPP was primary or channelopathy [P value $<0.001]$, whereas another 6 years study conducted on 31 patients by Christian Medical College at Vellore, Tamilnadu from 1995 to 2011 which reveals significant number of patients had secondary causes of HPP.

\section{CONCLUSION}

Our patients presenting with sudden onset of paralysis with markedly low Sr. $\mathrm{K}^{+}$levels is typical of primary HPP. The aetiology of HPP must be found early to prevent recurrence. Its symptoms are resolved completely and quickly following correction with oral $\mathrm{K}^{+}$(rarely IV) replacement therapy. Those HPP patients who did not respond to usual $\mathrm{K}^{+}$ supplementation therapy only needs further evaluations and study. HPP can be fatal if failed to diagnose and treat properly.

Treatment for secondary HPP, i.e. Distal RTA includes correction of dehydration with fluids and acidosis with alkali replacement therapy, which reduces urinary $\mathrm{K}^{+}$loss and $\mathrm{Na}^{+}$ depletion with sustained correction of metabolic acidosis, here $\mathrm{K}^{+}$supplementation is not necessary.

Another secondary HPP, i.e. GS was treated with $\mathrm{Mg}^{2+}$ and $\mathrm{K}^{+}$replacement therapy depending upon the symptoms and levels of hypomagnesaemia and hypokalaemia. Tab. Acetazolamide 250 to $500 \mathrm{mg}$ was given two times a day only for primary HPP and not for secondary HPP, because it may precipitate attack in type 2 HPP.

From our study we found that with the help of bed side investigations like ECG and Sr. Electrolytes, we diagnose HPP before ordering for CT and MRI of Brain and Neck.

\section{REFERENCES}

[1] Stedwell RE, Allen KM, Binder LS. Hypokalemic paralyses: a review of the etiologies, pathophysiology, presentation and therapy. Am J Emerg Med 1992;10(2):143-8. 
[2] Lehmann-Horn F, Rudel R. Channelopathies: the nondystrophic myotonias and periodic paralyses. Semin Pediatr Neurol 1996;3(2):122-39.

[3] Fontaine B, Fournier E, Sternberg D, et al. Hypokalemic periodic paralysis: a model for a clinical and research approach to a rare disorder. Neurotherapeutics 2007;4(2):225-32.

[4] Brenner RJ, Spring DB, Sebastian A, et al. Incidence of radiographically evidence bone disease, nephrolithiasis, and nephrolithiasis in various types of renal tubular acidosis. N Engl J Med 1982;307(4): 217-21.

[5] Lightwood R, Payne WW, Black JA. Infantile renal acidosis. Pediatrics 1953;12(6):628-44.

[6] Karet FE, Gainza FJ, Gyory AZ, et al. Mutation in the chloride-bicarbonate exchanger gene AE1 cause autosomal dominant but not autosomal recessive distal renal tubular acidosis. Proc Natl Acad Scintillating USA 1998;95(11):6337-42.

[7] Bentur L, Alon U, Mandel H, et al. Familiar distal renal tubular acidosis with neurosensory deafness: early nephrocalcinosis. Am J Nephrol 1989;9:470-4.

[8] Morris RC, Sebastian A. Renal tubular acidosis and fanconisyndrome. In: Wyngaarden JB, Fredrickson DS, Goldstein JL, et al. (eds) The metabolic basis of inherited disease. $5^{\text {th }}$ edn. McGraw-Hill, New York, 1983:P 1808.

[9] Simon DB, Nelson-Williams C, Bia MJ, et al. Gitelman's variant of bartter's syndrome, inherited hypokalaemic alkalosis, is caused by mutations in the thiazidesensitive Na-CI cotransporter. Nat Genet 1996;12(1):24-30.
[10] Bettinelli A, Bianchetti MG, Girardin E, et al. Use of calcium excretion values to distinguish two forms of primary renal tubular hypokalemic alkalosis: bartter and gitelman syndromes. J Pediatr 1992;120(1):38-43.

[11] Katopodis K, Elisaf M, Siamopoulos KC. Hypophosphataemia in a patient gitelman's syndrome. Nephrol Dial Transplant 1996;11(10):2090-2.

[12] Jurkat-Rott K, Lehmann-Horn F, Elbaz A, et al. A calcium channel mutation causing hypokalemic periodic paralysis. Hum Mol Genet 1994;3(8):1415-9.

[13] Struyk AF, Scoggan KA, Bulman DE, et al. The human skeletal muscle $\mathrm{Na}$ channel mutation $\mathrm{R} 669 \mathrm{H}$ associated with hypokalemic periodic paralysis enhances slow inactivation. J Neurosci 2000;20(23):8610-7.

[14] Servidei S, Mendell JR, Angelini C, et al. Genotypephenotype correlations of DHP receptor alpha 1subunit gene mutations causing hypokalemic periodic paralysis. Neuromuscular 1997;7(1):33-8.

[15] Venance SL, Cannon SC, Fialho D, et al. The primary periodic paralyses: diagnosis, pathogenesis and treatment. Brain 2006;129(Pt 1):8-17.

[16] Cogan MG, Rector FC. Acid-base disorders. In: Brenner BM, Rector FC. (eds) The kidney. $4^{\text {th }}$ edn. WB Saunders, Philadelphia 1991:P 737.

[17] Links TP, Zwarts MJ, Wilmink JT, et al. Permanent muscle weakness in familial hypokalaemic periodic paralysis. Clinical, radiological and pathological aspects. Brain 1990;113(Pt 6):1873-89.

[18] Miller TM, Miller HA, Kwiecinski H, et al. Correlating phenotype and genotype in the periodic paralyses. Neurology 2004;63(9):1647-55. 